\title{
УДК 327 \\ STABILISATION OF FAILED STATES - THE ROLE OF THE DEVELOPMENT POLICY ILLUSTRATED WITH AN EXAMPLE OF GERMANY
}

\author{
Anna Paterek \\ Krakowska Akademia im. Andrzeja Frycza Modrzewskiego, \\ ul. Herlinga Grudzińskiego, 1, Kraków, Polska, 30-705, tel. 503 7035, \\ e-mail:anpaterek@gmail.com
}

This article presents a synthetic analysis of the German development actions carried out bilaterally and aimed at stabilising dysfunctional states. The Author focuses on presenting the premises for the German development cooperation with weak states or those on the verge of failure through the perspective of foreign and security policies' aims and the examples of their implementation in the years 2010-2015.

Documents, statistic data, interviews with the key players in the German development assistance and international organisations(OECD among others), as well as primary sources in English and German constitute the source basis.

Germany attributes a special role to development cooperation in overcoming structural sources of contemporary threats and consolidation of peace. The erosion of statehood is one of the threats to regional and global security, and thus is a challenge for international development cooperation. At the same time, the reluctance towards military engagement abroad directs the German actions targeted at fragile states more towards stabilisation, security, and civil prevention of conflicts. ODA.

Key words: fragile states; development policy; development cooperation; Germany; assistance;

\section{Introduction}

The erosion of statehood has now become one of the dangers of both regional and global security and, thus, is the challenge for the international cooperation in development. An expression of this issue is the fact that the international community has recently become more and more interested in the cases of the countries that have been affected by fragility. And what is particularly noticeable in this issue is the engagement of the German development policy. This article focuses on the analysis of the strategic framework of the policy of Germany directed at fragile states. The author studies the assumptions of the inter-ministerial cooperation in the issue, its limitations, results and the perspectives of the German policy that concerns dysfunctional countries.

The challenges of the international cooperation for the development of the dysfunctional countries

According to the surveys conducted by the OECD, 50 countries that in 2015 were put on the list of the countries with an unstable situation are inhabited by $43 \%$ of the global population that lives on the poverty line with a daily rate of less than $\$ 1.25$ dollar per person [1]. Until 2030, the concentration of poverty in these countries might reach $62 \%$ [2, p. 15]. Moreover, half of them have remained on the OECD list

(C) Paterek Anna, 2017 
incessantly since 2007 . The inhabitants of 50 fragile states are at the moment $20 \%$ of the global population(1.4 billion people) and by 2030 their number will have risen to 1,9 billion and by 2050 - to 2,6 billion. Fragile states are characterised by many common features(structural problems and badly functioning institutions) but at the same time they differ among one another in many ways. The highest life expectancy rate in 2012 was that of Bosna and Hercegovina(76 years) and the lowest one was that of Sierra Leone(45). Whereas the median age of the people who live in these countries was 21, the global mean age that was 30(2013). The 2013 GDP rated from \$ 522 billion(Nigeria) to $\$ 1$ billion(Solomon Islands). As for the gross national income per person in 2013 it rated from $\$ 6,710$ (Iraq) to $\$ 270$ (Malawi). Out of 50 fragile states, 27 are the countries of low income. The region which is affected by instability the most is Sub-Saharan Africa with 28 fragile states [2, p. 33].

Despite the differences that exist in the way «fragility» is defined in the discourse of development [3], it is generally accepted that it is primarily characterised by the inability of the state to protect the citizens from violence, to provide them with basic services and by the fact that any of state actions and operations lack legitimacy. The OECD report from 2015 introduced five aspects that define the biggest risk and tendencies for fragility: 1) violence: the reduction of all the forms of violence; 2) justice: a common access to courts; 3) institutions: efficient, responsible and socially inclusive institutions; 4) stable economic basis: the support for the economic, social, and political inclusion; 5) immunity: the reinforcement of the capacities to overcome social, economic and ecological turmoil and crises[2, p. 46-49].

Fragility is thus perceived to be the challenge that requires multidimensional efforts in order to overcome it. Such a notion of the dysfunctionality of a country is supposed to contribute to the identification of the national and international aid priorities that take into consideration the variety of aspects and levels of fragility, and so it should facilitate the allocation of the international funds. Destabilisation of a state is conductive to varied costs in development, economy and security that are felt both locally and globally. The assumption that fragile states are the source of varied dangers for the international security is expressed in shaping the criteria for granting Official Development Assistance (ODA) by the countries that belong to the OECD Development Assistance Committee (DAC). In 2007, half of the means devoted to fragile states was granted to four of them, which was the result either of the current challenges to the international security (Afghanistan and Iraq) or of the importance of these countries in the already unstable regions (Ethiopia and Pakistan).

Any efficient way of supporting development is particularly difficult in those states that are affected by fragility. It is the result of the deficiencies of state institutions and limited competencies that are necessary to set the framework for development and for implementing ODA. The difference between the will and political capacity of the benefactors and the priorities of the donors leads, in consequence, to granting a reduced financial support to the countries that need it the most. In the discussions concerning dysfunctionality it is often emphasized that there is a need to match the engagement of the external entities in fragile states, ground aid priorities in the local conditions, and take into consideration political, social, historical, cultural and economic diversity. It is often the case that although donors 
Anna Paterek

ISSN 2078-4333. Вісник Львівського університету. Серія міжнародні відносини. 2017. Випуск 41 113

pay attention to coordinating their help in the situation when a country is dysfunctional, the current needs and geopolitical interests often distort the long-term plans for the development of these states that are applied to local conditions, features and dynamics.

Within the recent years all the measures taken in order to support the states that are fragile or affected by conflicts were in the centre of attention of the ODA donors. In 2008 and with the recommendation of the Third High Level Forum on Aid Effectiveness, the International Dialogue on Peacebuilding and State building (IDPS) was established [4]. On 30 November, 2011 in Pusan the IDPS participants accepted the plan of the New Deal for Engagement in Fragile States[5]. This plan establishes five priority goals for building peace and statehood (Peacebuilding and State building Goal, PSGs) in fragile states: 1) legitimate politics: strengthening the legitimacy of political institutions and of the process of solving conflicts; 2) security: establishing and strengthening the security of the citizens; 3) economic foundations: providing employment and improving living standards; 4) revenues and services: the management of state revenues and services [6].

German engagement in the development of fragile states - the priorities and strategic aims

The conditions that shape the framework of the German development policy conducted by the SPD/Greens coalition at the beginning of the $21^{\text {st }}$ century resulted in strengthening the importance of the cooperation for development. This policy became a part of the complex global policy for peace that was directed at the support of the structural changes that were supposed to reduce poverty, support sustained development, promote democracy, human rights, the sustained use of natural resources and combat the sources of conflicts in the partner countries [7, p. XI]. From then on, the development policy became a constitutive segment of German security policy [8, p. 489] whose aim was to establish good living standards in the developing countries and thus secure the future.

The 2004 action plan called Civil Prevention of Crisis Situations, Problem-solving and Peacebuilding exposed the meaning of non-military aspects of crisis prevention and the systematic inclusion of social factors [9, p. 18]. The same concerns the White Book on the Security Policy of the Federal Republic and the Future of Bundeswehr from 2006 and 2016 respectively that directed the German policy for fragile states primarily with reference to crisis prevention. It aims at a long-term action with the harmonious use of the accessible instruments so that the sources of conflicts will be combatted, the peaceful balance of the interests between the states and unstable regions will be supported, the reasons for instability will be overcome and the transformation processes will be reinforced [10, s. 3]. The most recent of the listed documents from 13 July 2016 underlines that the fragile statehood both the one that is the neighbour to Germany and the distant one «indirectly influences Germany too». Therefore, «early recognition and prevention of the failure of a state and the long term stability of the dysfunctional or failed states require a related approach which will assure fast and proper mobilisation of the proper instruments of crisis prevention within the framework of foreign, development, and security policy» [11, p. 40]. 
Moreover, the new approach of the German development policy outlined by the Federal Ministry for Economic Cooperation and Development(Bundesministerium für wirtschaftliche Zusammenarbeit und Entwicklung - BMZ) in 2011 and entitled Providing Opportunities - Developing the Future [12] defines the actions in the situations of instability as one of the five most important grounds on which sustained development is based. This document founds German engagement for development on universal values and strategic interests. Founding the cooperation for development on economic, security and humanitarian presumptions is the condition of the cooperation of the BMZ with other ministries and institutions such as the Federal Ministry of Defence (Bundesministerium der Verteidigung - BMVg) and Bundeswehr which, in turn, follows the government's principle of «related security». An example of such an approach are the inter-ministerial directives concerning fragile states that were accepted in 2012 by the Ministry of Foreign Affairs (Auswärtiges Amt - AA), BMVg and the BMZ [10]. They set the framework of the German engagement in the counties affected by the problems that result from fragility. They are implemented, for example, thanks to task forces whose competence is working out a concise idea of actions(like in the region of Sahel, Yemen or Syria). Medium and long-term aims of the German engagement in the fragile states mean the support of building and strengthening the statehood, shaping the processes of transformation taking further steps to prevent conflicts and crises, and actions to consolidate peace. The pragmatic approach in actions for development, particularly in the case of the dysfunctional countries emphasizes understanding local conditions and the principles of the local ownership(strengthening the responsibility of partner states) and the do no harm principle(not contributing to problems being deepened) [10; 13, p. 18].

In 2007, the BMZ published, for the first time, the programming document that refers to the group of states that are affected by unfavourable conditions entitled Transformation Directed at Development with the Fragility of State and Bad Government [14]. This document was expanded in 2013 by a strategy that concerns the engagement for development in the context of conflict, fragility and violence [13]. It acknowledges the fact that the need to act in such states is one of the most important factors of sustained development. More than half of the partner states of the German cooperation for development are in the region affected by the conflict, fragility or violence. Fragile states negatively affect their neighbours and, in general, the security in the region. Weak or non-existent state structures constitute the source of dangers on the global scale. Therefore, the primary aim of the German foreign, development and security policy is to contribute to international peace and security. Actions taken for peace were subject to the peace and state building (PSGs) aims that have been listed above, including three additional points that justify the essence of the development policy: 1) overcoming the sources of conflicts, fragility and violence; 2) enhancing the skills for peaceful conflict solving; 3 ) establishing the conditions for the development that is peaceful and favourable to social inclusion [13, p. 11]. The most important challenges for efficient efforts for development in the situations of fragility included low capacity of aid resources mobilisation, corruption on a broad scale and the limited acceptance for the state structures, the dynamically changing environment, and varied forms of violence that limit the framework of pro-development activities [13, p. 16]. 
Anna Paterek

ISSN 2078-4333. Вісник Львівського університету. Серія міжнародні відносини. 2017. Випуск 41 115

The Charter for Future. One world - Our Responsibility that was elaborated on in 2014 under the supervision of a Christian Democrat, Gerd Müller, emphasizes the importance of actions directed outside, especially in the times of increasing conflicts and military clashes as the economically interrelated world requires international cooperation in order to overcome common problems. The charter sets the hierarchy of the German priorities while implementing Agenda 2030 [16], for example actions for peace and strengthening security [15, p. 38-41].

The intensification of the efficiency of German efforts for development of fragile states is made possible thanks to the cooperation of the government and the academic world. The example here is a special think tank called Sonderforschungsbereich 700 which is financially supported by Deutsche Forschungsgemeinschaft (DFG). Among the tank's tasks are the development of the basic presumptions of the German foreign policy concerning fragile states, mainly with reference to the support of the rule of law, democracy and the reforms of the security sector. Another case here are the research projects of the German Development Institute (Deutsches Institut für Entwicklungspolitik - DIE) which is financed by the BMZ.

\section{Bilateral aspect of the German development cooperation in fragile states}

Germany is in the world forefront in terms of aid donations for the developing countries. According to the initial OECD data for the year 2015, the amount of the Official Development Assistance (ODA) offered by Germany was the third largest among 28 members of the Development Assistance Committee, after the USA and Great Britain. The German ODA in 2015 was 17,78 billion USD, which constituted $0,52 \%$ DNB and was the highest to date [17, p. 199]. In comparison to the year 2014, its value increased in real terms by $25.9 \%$, mainly due to the increase of the internal costs connected with refugees [17, p. 199]. From 2009, the part for development activities carried out multilaterally was consistently reduced for the benefit of bilateral aid. In 2014, bilateral aid constituted 74,3\% of the German ODA [17, p. 199].

The German Official Development Assistance is carried out in cooperation with 50 partner countries within the framework of thematic and regional programmes. In 2014 , ten beneficiaries received 37,4\% of the German bilateral aid, and five out of them were fragile(Afghanistan, Myanmar, Syrian Arab Republic, Egypt, Côte d'Ivoire). The support for the states struggling with fragility was $\$ 3,8$ billion, i.e. $26,8 \%$ of the bilateral ODA in 2014. At the same time, the least developed countries benefited from $20,6 \%$ of the bilateral ODA ( $\$ 3$ billion) [17, p. 200].

In the years 2013-2014, the addressee of $15 \%$ of the German bilateral aid were the Sub-Saharan countries, $13 \%$ - the countries of North Africa and the Middle East, and of $19 \%$ - the countries of South and Middle Asia [17, p. 200]. The regional priority of the BMZ activities is Africa, which is the beneficiary of $50 \%$ of the bilateral development aid. The countries from this region receive annually the total assistance of 1,2 billion euros [18, p. 4]. The biggest recipients of the German development aid (on average in the years 2010-2014) were: the Democratic Republic of Congo, Egypt, Mozambique, Kenia and Tanzania [18, p. 5].

The ranked list of the partner countries receiving bilateral development assistance, according to the amount of the aid in 2014, included, among others, the following fragile states: Afghanistan, Myanmar, Syria, Egypt, Yemen, Pakistan, South Sudan, 
Bangladesh, Cote d'Ivoire, Kenia, the Democratic Republic of Congo, Ethiopia, Cameroon, Tanzania, Nigeria, Mali, Mozambique, Iran, Burkina Faso, and Cambodia [19].

In the years 2011-2013, Germany was among the ten largest DAC donors of aid for African countries, taking the fourth position after the United States, France, and Great Britain [20, p. 4]. The government strategy of foreign policy towards Africa from June 2011 [21] emphasises its immense potential in international relations. Even a bigger significance is given to this continent by the guidelines of the African policy presented by the federal government on 21 May 2014 [22]. According to its provisions, the efforts of the international community should focus on the prevention of poverty and fragility, fighting threats and overcoming crises. The fragility of African countries is a challenge for Europe. The countries and regions affected by fragility are characterised by weak institutions and statehood which can lead to failure. Fragile states, especially in North Africa and the Sahel region, are a fertile ground for organised crime groups and terrorist organisations, whose activity is not limited to Africa only. Therefore, the priorities of the German engagement in Africa are, among others: 1) strengthening the regional integration, including the engagement of fragile states and encouraging them to take responsibility; 2) supporting peace and security within the framework of the African Peace and Security Architecture (APSA) [23] 3) decreasing fragility, conflicts and violence; preventing the violation of Human Rights.

On the other hand, the German activities for development on Afghanistan are mostly directed at the improvement of living conditions of its inhabitants. In the years 2001-2012, the German support for the civil reconstruction and development of this country amounted to a total of 2,9 billion euros. Initially, it was meant to be 80 million euros annually in the years 2002-2010. Until 2009, the amount increased to 230 million euros. In 2010, the financial aid was increased to the annual amount of 430 million euros (until 2016, 250 million from the BMZ, 180 million from AA). 800 million euros were the means for activities within the stability package for Afghanistan in the years 2008-2013, and about 1,14 billion euros were assigned for BMZ development initiatives in the same period. Therefore, Afghanistan was «a constant most important beneficiary of the German civil aid» [24]. The implementation of the aid was carried out through financial instruments of the German Development Bank and technical support of the German Association for International Cooperation (Deutsche Gesellschaft für Internationale Zusammenarbeit - GIZ). Thereby, Germany has been the largest, after the United States and Japan, donor of aid for Afghanistan. The means from the $2015 \mathrm{BMZ}$ budget, provided for on the basis of intergovernmental agreement, amount to 245 million euros. Some of the assistance depends on the progress in carrying out reforms, especially in good governance. Additionally, from 2015 the development of the Afghan security sector will be financed from the BMVg budget. The German-Afghan development cooperation concentrates on the following aspects: good governance, supply of energy and drinking water, waste water purification, sustainable economic development, and elementary and vocational education. The development activity focuses on six provinces in Northern Afghanistan (Baghlan, Balch, Badakhshan, Kunduz, Samangan 
Anna Paterek

ISSN 2078-4333. Вісник Львівського університету. Серія міжнародні відносини. 2017. Випуск 41

and Tahar) and the capital - Kabul. The German civil personnel in Afghanistan consists of 300 employees, including $30 \%$ of women, more than 1,8 thousand local associates, out of which number $16 \%$ are women.

The termination of the ISAF mandate at the end of 2014 entailed the adoption of a new German policy for Afghanistan [25]. According to the international obligations, Germany will still provide Afghanistan with the aid of 430 million euros annually (250 million from the BMZ and 180 million from the AA budget). Taking into consideration the new conditions, five priorities of the Afghan policy have been established for the years 2014 - 2017: 1) employment as a factor preventing extremism; 2) justice thanks to good governance; 3) sustainable support for the people from the central and outermost regions; 4) development engagement in the controlled safe districts; 5) support with simultaneous requirements and their execution [25]. The last aspect was underlined by Minister of Development Cooperation, Gerd Müller, during his visit to Kabul: «I would like to strongly emphasise that the delivery of our pledges will depend in the future on the progress in the implementation of reforms in Afghanistan» [26].

\section{Conclusion}

The engagement of Germany for the countries struggling with the problems of fragility is connected with the adopted vision of development policy which is not only an investment in its own security, but it also allows to shape the feeling of shared responsibility. The dynamics of the challenges connected with the erosion of statehood in Afghanistan or the Sub-Saharan countries proves that stability and security are an indispensable condition for the appropriate socio-economic development and it is also an expression of the belief that strategies and activities in foreign, development and security policies should be integrated as it is exemplified by the German engagement in Afghanistan. However, with regard to its scale and negligible predictability of effects, in the long-term perspective there appears a paradox of the continuation of the state's competences and legitimacy erosion despite the support. A twelve-year-long military presence of Germany devoured about 8,8 billion euros, and the withdrawal of the German soldiers until the end of 2014 - about 66,2 million euros [27]. Yet, comparing the costs of military and civil presence of the Federal Republic of Germany in Afghanistan fails because, among other things, the limited absorptivity of civil aid restricts its distribution and does not allow to increase its level. Nevertheless, the consequences of external inactivity toward the problem of developing countries dysfunctionality would result in a growing risk for both the donors' societies and the fragile states.

\section{REFERENCES}

1. There are several ranked lists and classifications of states' fragility prepared, among others, by the OECD, the World Bank, the African Development Bank and Fund of Peace. The list of fragile states adopted in this article is the one which the OECD refers to in the reports Fragile States 2014 and States of Fragility 2015, www.oecd.org.

2. OECD, Aspekte der Fragilität 2015. Lassen sich die Ambitionen der Post-2015-Agenda erfüllen? Paris 2015 . 
3. Faust J., Grävingholt J, Ziaja S., Foreign Aid and the Fragile Consensus on State Fragility, Discussion Paper 2013, No 8.

4. https://www.pbsbdialogue.org/en/id/origins/ (access on 12.10.2016).

5. http://www.g7plus.org/node/1 (access on 12.10.2016).

6. Building Blocks to Prosperity: The Peacebuilding and Statebuilding Goals, accessible at: www.oecd.org (access on 12.10.2016).

7. BMZ, Elfter Bericht zur Entwicklungspolitik der Bundesregierung, 2001, http://fa1.spdberlin.de/Dokumente/bregez11.pdf (access on 12.10.2016).

8. Hacke Ch., Die Außenpolitik der Bundesrepublik Deutschland. Von Konrad Adenauer bis Gerhard Schröder, Frankfurt/M-Berlin 2003.

9. Aktionsplan. Zivile Krisenprävention, Konfliktlösung und Friedenskonsolidierung, 2004, www.ag-friedensforschung.de/themen/Aussenpolitik/ aktionsplan.pdf (access on 12.10.2016).

10. Ressortübergreifende Leitlinien. Für eine kohärente Politik der Bundesregierung gegenüber fragilen Staaten, August 2012, accessible at: www.bmz.de.

11. Bundesregierung 2016, Weißbuch 2016 - zur deutschen Sicherheitspolitik und zur Zukunft der Bundeswehr, accessible at: https://www.bmvg.de.

12. Chancen schaffen - Minds for Change. Zukunft entwickeln - Enhancing Opportunities, August 2011, accessible at: www.bmz.de.

13. Entwicklung für Frieden und Sicherheit. Entwicklungspolitisches Engagement im Kontext von Konflikt, Fragilität und Gewalt, «BMZ-Strategiepapier» 2013, No 4.

14. Entwicklungsorientierte Transformation bei fragiler Staatlichkeit und schlechter Regierungsführung, März 2007, accessible at: www.bmz.de.

15. BMZ, Die Zukunftscharta «EINEWELT - Unsere Verantwortung» 2014 https://www.zukunftscharta.de/das-dokument.html (access on 12.10.2016).

16. Adopted in September 2015 at the UN Forum the new framework for development policy for the years 2015 - 20130, the so-called Sustainable Development Goals (SDGs) are an extension and continuation of the Millenium development Goal.

17. OECD, Development Co-operation Report 2016, http://www.oecd.org/dac/ development-cooperation-report-20747721.htm (access on 12.10.2016).

18. Die neue Afrika-Politik des BMZ -. Afrika auf dem Weg vom Krisen- zum Chancenkontinent, «BMZ-Strategiepapier» 2014, No 6.

19. Bilaterale ODA - Rangliste 2014, 13.01.2016, http://www.bmz.de/de/ zentrales_downloadarchiv/Ministerium/ODA/3_D3_Bilaterale_ODA_Rangliste_2014_Spalte_2.pdf.

20. Development Aid At A Glance https://www.oecd.org/dac/stats/documentupload/2\%20Africa\% 20-20Development20Aid\%20at\%20a\%20Glance\%202015.pdf.

21. Deutschland und Afrika: Konzept der Bundesregierung, 2011, www.auswaertiges-amt.de/cae/ servlet/contentblob/581096/publicationFile/155321/110615-Afrika-Konzept-download.pdf (access on 10.08.2016)

22. Afrikapolitische Leitlinien der Bundesregierung, www.allemagne.diplo.de/contentblob/4262948/ Daten/4876190/01strategieafriquedtschdatei.pdf (access on 10.08.2016).

23. An example of this is the transregional programme for the African police implemented by the German Association for International Cooperation (Deutsche Gesellschaft für Internationale Zusammenarbeit - GIZ), which encompasses activities for building police institutions capabilities. Since 2009, 11 countries of the Sub-Saharan Africa have taken part in it. In effect, 125 police stations and border inspection post have been established and equipped. The programme supports sending African police officers to African and international missions and building the police skills of the African Peace and Security Architecture (APSA). Its implementation was completed in 2012 in Liberia, Ruanda, Sierra Leone, and the Central African Republic; it is continued in Burundi, Cote d'Ivoire, the Democratic Republic of Congo, Nigeria, Mauretania, South Sudan, and Chad.

24. Fortschrittsbericht Afghanistan 2014, November 2014, s. 64, docs.dpaq.de/ 8336-141119fortschrittsbericht_afg_2014.pdf (access on10.10.2016).

25. Deutsche Zusammenarbeit mit Afghanistan, accessible at: www.bmz.de; Neue entwicklungspolitische Strategie für die Zusammenarbeit mit Afghanistan im Zeitraum 2014-2017, accessible at: www.bmz.de. 
Anna Paterek

ISSN 2078-4333. Вісник Львівського університету. Серія міжнародні відносини. 2017. Випуск 41

26. Bundeswehra ma pozostać w Afganistanie. Uwikłanie w starcia zbrojne niewykluczone, 18.11.2014, accessible at: www.dw.com/pl.

27. After the ISAF termination the Bundeswehr with 850 soldiers is present in Afghanistan within the framework of the new training and advisory mission «Resolute Support»; see: Prasa: Bilans afgańskiej misji Bundeswehry, 20.11.2014, accessible at: www.dw.com/pl; Błędne planowanie: Niemcy podsumowują koszty misji w Afganistanie, 21.03.2015, accessible at: www.dw.com/pl.

Стаття надійшла до редколегії 10.12.2016

Прийнята до друку 23.12.2016

\title{
СТАБІЛІЗАЦІЯ НЕСПРОМОЖНИХ ДЕРЖАВ - РОЛЬ ПОЛІТИКИ В ЇХНЬОМУ РОЗВИТКУ НА ПРИКЛАДІ НІМЕЧЧИНИ
}

\author{
Анна Патерек \\ Краківська академія ім. Анджея Фрича Моджевськєго, \\ вул. Х. Груджіньськєго, 1, м. Краків, Польща, 30-705, тел. 503703547, \\ e-mail:anpaterek@gmail.com
}

Подано короткий аналіз діяльності Німеччини, виконаний на двосторонній основі 3 метою стабілізації та розвитку неспроможних країн. Автор концентрує свою увагу на презентації цілей співробітництва в галузі розвитку як між Німеччиною та слабкими державами, так і між тими країнами, що знаходяться на межі зриву програмних цілей зовнішньої політики і політики безпеки.

3 метою написання статті проаналізовано документи, статистику, інтерв'ю основних учасників німецької політики в області розвитку і міжнародних організацій, а також англо- та німецькомовну літературу.

Німеччина приділяє особливу роль співробітництву 3 метою розвитку в подоланні структурних джерел сучасних загроз і збереження миру у світі. Руйнування державності $є$ однією із загроз регіональної та глобальної безпеки, тому й вважається найбільшим завданням в області розвитку міжнародної співпраці. Водночас Німеччина не бере участі у військових діях на територіях нестабільних держав, а, навпаки, намагається уникати конфліктів за рахунок стабілізації і надання безпеки.

Ключові слова: нестабільні держави; політика розвитку; співробітництво в цілях розвитку; Німеччина; допомога; ODA. 